\title{
A Diabetic Gentleman with Fever and Abdominal pain
}

\author{
A DAS $^{\mathrm{a}}, \mathrm{S} \mathrm{ISLAM}^{\mathrm{b}}$, MA KAHHAR
}

(J Bangladesh Coll Phys Surg 2016; 34: 175-177)

A 65-year-old male admitted in Dhaka Medical College Hospital with the complains of pain in left flanks for 5 days and fever for 3 days. Pain was constant, severe, cramping in nature associated with nausea and vomiting. He also complained of dysuria for last 8 days. Fever was intermittent in nature comes with chills and rigor subsided with sweating. Maximum rise of temperature was $102^{\circ} \mathrm{F}\left(38.9^{\circ} \mathrm{C}\right)$. Following $4^{\text {th }}$ day of admission he developed soft tissue swelling over his left flanks. He was diabetic for last 5 years was on oral hypoglycemic drugs but stopped drugs for last 6 months.

The vital signs showed blood pressure of 100/60 mm $\mathrm{Hg}$ at presentation, pulse rate of 106 beats/min, respiratory rate of 25 breaths/min, breathing was uraemic and temperature of $103^{\circ} \mathrm{F}\left(39.4^{\circ} \mathrm{C}\right)$ was recorded. On examination, the patient was conscious, but mildly disoriented, and there was tenderness in the left renal angle, soft tissue pitting oedema localized to left flanks, but all the other systems were normal.
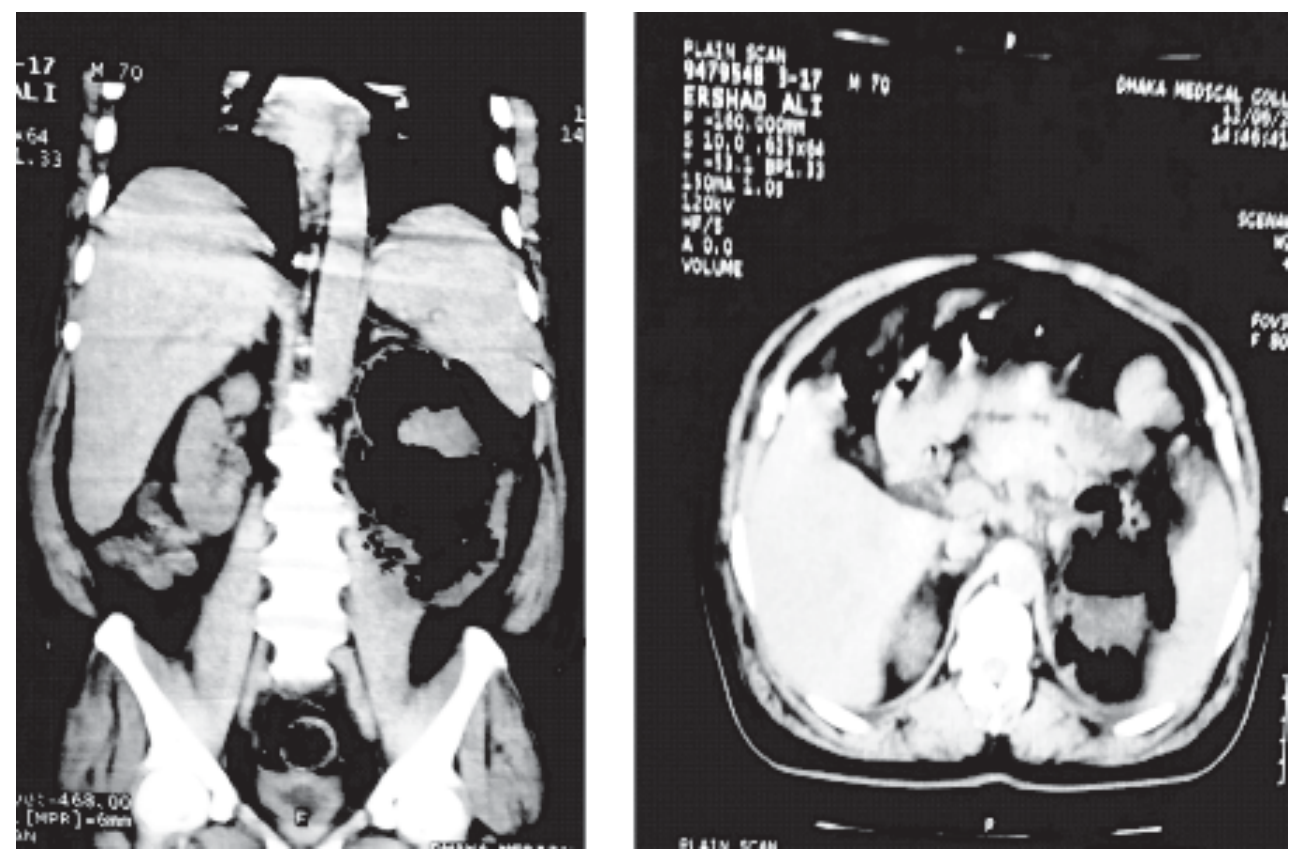

CT SCAN abdomen : Emphysaematous pyelonephreitis (EPN)- class IIIa with left psoas muscle inflammatoty changes.

\footnotetext{
a. Dr. Aparna Das, Asso. Prof. Dept. of Medicine, Dhaka Medical College.

b. Dr. Shahidul Islam, Honorary Medical Officer, Dept. of Medicine, Dhaka Medical College

c. Prof. M Azizul Kahhar, Prof. of Medicine, Dhaka Medical College.

Address of Correspondence: Dr. Aparna Das, Asso. Prof. Dept. of Medicine, Dhaka Medical College. Email : aparna _0191@yahoo.com
} 


\section{Investigations are given below}

1. $\mathrm{CBC}$

$\mathrm{Hb}$

WBC

Neutrophils

Platelete count

ESR

2. Urine RME

Sugar

Albumin

Pus cell

$\mathrm{RBC}$

3. Urine C/ S- growth of klebsiella

4. Blood C/ S - No growth

4.S. Cratinine

5. FDP

6. D- dimer

7. Blood sugar Fasting- $10 \mathrm{mmol} / \mathrm{L}$

8. Plain Xray KUB region- Gas shadow present in left renal area.

9. USG Whole abdomen: Huge intra-abdominal gas with non-visualized left kidney.

\section{$11.4 \mathrm{gm} / \mathrm{dl}$}

$25,000 / \mathrm{cmm}$

$87 \%$

$24,000 / \mathrm{cmm}$

$32 \mathrm{~mm}$ in $1^{\text {st }}$ hour
$+$

plenty

plenty

$4.09 \mathrm{mg} / \mathrm{dl}$

$20.17 \mathrm{Ug} / \mathrm{ml}$

$>4.0 \mathrm{Ug} / \mathrm{ml}$

2 hour after breakfast- $16 \mathrm{mmol} / \mathrm{L}$
The patient was diagnosed as a case of emphysaematous pyelonephretis with Septicemia with acute renal failure. His blood sugar controlled with insulin. Antibiotic inj. Meropenum and inj. Ceftazedime started according to culture of urine (klebsiela). He responded well with medical management and become afebrile in $1^{\text {st }}$ week. His WBC count reduced to $11,100 /$ $\mathrm{cmm}$ after 3 weeks and renal function improved to $1.2 \mathrm{mg} /$ dl after 2 weeks. Due to absence of any complications or features of sepsis after 4 weeks of injectable antibiotics the patient was discharged on oral antibiotics for a further 2 weeks.

\section{Discussion:}

Emphysematous pyelonephritis is a well-known condition which mainly affects the diabetic population (90\%) and seen in patients with chronic diabetes characterized by formation of gas in renal parenchyma. It has a strong female preponderance with female tomale ratio of 5:1, mean age of occurrence is around the fifth decade, and most often it involves left kidney in almost $60 \%$ of cases ${ }^{1}$.Patient usually present with abdominal pain , fever and tenderness in renal angle.

TABLE- I. Emphysematous pyelonephritis (EPN) classification by Huang and Tseng ${ }^{2}$

Class Description

Class I :Gas in collecting system only

Class II: Parenchymal gas only

Class IIIa: Extension of gas into perinephric space

Class IIIb: Extension of gas into pararenal space

Class IV: EPN in solitary kidney, or bilateral disease

Management is now based on CT scan based classification by Huang and Tseng. Class I and II EPN can be managed by medical therapy alone or combined with percutaneous drainage, have a success rate of $66 \%$, while the mortality rate for treatment with antibiotics alone ranges from $40 \%$ to $90 \%$.For classes III and IV, antibiotic therapy and PCD may be attempted but ultimately nephrectomy may be necessary. 
A recent case series describes eight cases of EPN with medical management alone. Of these eight cases, four were class IV EPN, five cases required haemodialysis, whereas four needed percutaneous drainage. The authors successfully used injections of imipenem for 10 days in five patients, cefoperazone + sulbactam for 14 days in two patients, and piperacillin + tazobactam for 14 days in one patient. ${ }^{3}$. Recent update recommended more conservative management , there are case reports of successful treatment with percutenous drainage and antibiotics ${ }^{3-5 .}$

Our patient recovered well with conservative management without percutenous drainage and surgery. Conservative manegment could be done with close monitoring and follow up the patient But nephrectomy is the best way to treat advance disease.

\section{References:}

1. Pontin AR, Barnes RD. Current management of emphysematous pyelonephritis. Nat Rev Urol 2009;6:272- 9.

2. Huang JJ, Tseng CC. Emphysematous pyelonephritis: clinicoradiological classification, management, prognosis, and pathogenesis. Arch Intern Med 2000;160:797-805.

3. Kolla PK, Madhav D, Reddy S, Pentyala S, Kumar P, Pathapati RM. Clinical profile and outcome of conservatively managed emphysematous pyelonephritis. ISRN Urol 2012;2012:931982

4. Flores G, Nellen H, Magaña F, Calleja J. Acute bilateral emphysematous pyelonephritis successfully managed by medical therapy alone: a case report and review of the literature. BMC Nephrol 2002;3:4.

5. Tahir H, Thomas G, Sheerin N, Bettington H, Pattison JM, Goldsmith DJ. Successful medical treatment of acute bilateral emphysematous pyelonephritis. Am J Kidney Dis 2000;36:1267-70. 